\title{
The Constitutional Law Research Trends and Plagiarism Problem in State Islamic University
}

\author{
Ija Suntana \\ UIN Sunan Gunung Djati Bandung \\ ijasuntana@uinsgd.ac.id
}

\begin{abstract}
Abstrak
Hukum Tata Negara merupakan bidang yang relatif baru di Universitas Islam Negeri Sunan Gunung Djati, yang memiliki tiga subjek kajian, yaitu ilmu perundang-udangan (siyasah dusturiyyah), regulasi pembangunan ekonomi negara (siyasah maliyyah), dan hubungan luar negeri (siyasah dauliyyah). Tujuan dari penelitian ini adalah untuk menemukan tren penelitian bidang Hukum Tata Negara sekaligus memetakan prosedur penelitian di bidang tersebut dan proyeksi ke depan. Analisis bibliometrik digunakan dalam penelitian ini dengan basis data skripsi mahasiswa Hukum Tata Negara selama lima tahun (2013-1017) sebagai sumber data utama, dengan jumlah sampel sebanyak 80 skripsi. Penelitian ini menemukan bahwa tren penelitian para mahasiswa Hukum Tata Negara UIN Sunan Gunung Djati lebih memilih subjek ilmu perundangundangan dibanding subjek regulasi pembangunan ekonomi negara dan regulasi internasional. Dalam hal metode, tren pilihan metode deskriptif sangat tinggi, mencapai $45 \%$, sedangkan pilihan terendah jatuh pada metode komparatif, hanya mencapai 6\%. Sebanyak 41 konsep dipilih oleh para mahasiswa HTN dalam penelitian, dengan pilihan paling banyak pada empat konsep, yaitu implementasi peraturan, aturan pelaksanaan undang-undang, peraturan daerah, dan penerapan pasal. Konsep yang jarang dipilih adalah regulasi internasional dan pengelolaan kekayaan negara. Terkait orsinalitas penelitian, dengan menggunakan aplikasi Turnitin, ditemukan sebanyak 28 skripsi terindikasi memiliki kemiripan dengan penelitian-penelitian sebelumnya dan sebanyak 52 skripsi dianggap wajar dari sisi kategori orsinalitas penelitian.
\end{abstract}

Kata Kunci: Subjek penelitian, konsep penelitian, keaslian

\begin{abstract}
The objective of this research was to find out research trend in constitutional law area as well to map research procedures in the said area and its projection in the future. Bibliometric analysis was applied, using 80 theses as sample from constitutional law bachelor degree student theses data base, with time range from 2013 to 2017. The research result shows that the Constitutional Law students gave extra preference to legislation studies rather that other subject. In methodological matters, the trend shows that most of research used descriptive methodology (45\%) and only few utilized comparative methods (6\%). At least 41 concepts were chosen by the students, with top four concepts are the enactment of regulations, the implementing regulations of Acts, the local government regulations, and the enactment of an article. The less chosen concepts are international law/regulations and state treasury management. From research originality aspect, by
\end{abstract}


using Turnitin application, there are 28 theses that have similarity indication with previous researches (with various typologies) and 52 theses are acceptable.

Keywords: research subject; research concept; originality.

\section{INTRODUCTION}

Constitutional law is a relatively new subject in State Islamic University. To set future plan, there is a need to perform a research on student's research subject, methodology, concept, and originality at the said program. Constitutional law that developed by State Islamic University has three subject research, which are legislation studies, state economic development regulations, and international relation.

Methodology happens to be fundamental issues in every research activities. It relates to how knowledge being comprehended, explained, verified, evaluated, explored, investigated, and interpreted (Ngulube, 2015:125). The quality of information and knowledge from any studies and science depend on the applied methodology. This methodology will guard a research process in a strict manner to reach the research objective.

Any research that has been conducted consistently and appropriately has positive effect in improving the quality of human life and the knowledge itself (Serenko and Bontis, 2009: 4). The selection of appropriate research methods is needed to create the concept of research problems and describe the examined phenomenon. As reported by Stallings and Ferris, it is not rare that field researchers use wrong method when conducting their research (Stalling and Ferris, 1988: 585).

Although Constitutional Law is a new discipline at State Islamic University, it can be expected that student research results provide important information about the knowledge management of the subject. As an applied science with influence from other fields, the Constitutional Law requires explicit attention on research procedures, so that this research will be part of a reflective evaluation.

According to above mentioned description, this study is driven by a question, how the research method is applied in Constitutional Law studies? Constitutional Law students' theses that were published between 2013 and 2017 are used to respond the research question. The applied subjective indicators to determine the said time range will be explained further at the Discussion of materials and methods part. From the available literatures, it is found that researches related to knowledge management in particular field gave more emphasis on research output factors, such as the intensity and volume of research results publication (Jordan, Amade, and De Clercq, 2013: 453), rather than the research methods aspects. 
Meanwhile, a very strong challenge for researchers and becomes a crucial problem in many universities today is plagiarism (Shenton, 2010: 75). From moral point of view, plagiarism offends human moral dignity, because it is related to the honesty value. From legal standpoint, it is a violation to intellectual rights (Belyaeva, 2012: 481). Although the writing originality barometer is very formal and subjective (Collier and Vallance, 1993: 510) depends on who sees it, it remains as an instrument to measure the science integrity. Related to that, the research originality of Constitutional Law students is important to note in this research.

\section{LITERATURE REVIEW}

Knowledge management research on research trends receives high attention in academic communities. A number of library-based reviews covering various topics of knowledge creation are widely practiced (Hahn and Subramani, 2000: 302). The core concepts of a discipline, definition, meaning, and significance have been widely discussed (Alavi and Leidner, 2001: 107), as well as the process of knowledge.

Nonaka and Peltokorpi (2006) reviewed twenty articles that are widely quoted in leading journals. Both of them classified articles based on their strengths and weaknesses in terms of publication. Likewise, Guo and Sheffield (2007) explored the results of research published between 2000 and 2004. They analyzed 160 articles, with an analysis focus on the aspects of research paradigm used by researchers. They found that the research paradigm in the articles had a profound imbalance between the use of positivist paradigm and non-positivist paradigm.

Other researches that related to research trends were conducted by Earl (2001) Hansen, Nohria, and Tierney (1999). They focused on studies of intellectual and social capital in research results, as well as focusing on studies of information technology needs as knowledge support. In addition to Hansen et.al., Dunford (2000), Schulz and Jobe (1998), Kautz (2002), also Scheepers, Venkitachalam, and Gibbs (2004) did the same research focus.

In terms of the methodological focus and content, the aforementioned studies are more interested in the classification of publications, but not into the methodological aspects, subjects, concepts, and research originality. For this reason, this study provides a broader contribution by discussing applied approaches, data collection methods, designs, themes, and constructions.

Meanwhile, further exploration upon those studies showed that research on knowledge management of Constitutional Law was not found. Cronin (2001) was more concern on information disciplines, Roztocki and Weistroffer (2015) were more interested in communication disciplines (2015), and Shin (2017) preferred medical discipline. Floress, 
Bescta, Meyer, and Reinke (2017) chose educational disciplines; as did as Göksu, Özcan, Cakir, and Göktas (2017) who were interested in the theme of the teaching curriculum module (2017).

Considering the literatures above described, it can be argued that research on the Constitutional Law discipline has a strong reason to be done and assure its originality. This study will provide an extensive overview and in-depth analysis of the important issues contained in constitutional law research.

\section{METHODS}

\section{Research Design}

This research was conducted at Constitutional Law Study Program, Faculty of Sharia and Law, State Islamic University Bandung, Indonesia. Bibliometric analysis was applied in this study with Constitutional Law student's theses database as the main data source. Most of recent studies apply bibliometrics to analyze data in form of publication citation indices, both in journals and proceedings (Xie, Zhan, and Ho, 2008: 113). This analysis can map and define topics that may become the focus of future researches (Bolivar, Munoz, and Hernandez, 2012: 79). To recognize research trends, bibliometric methods are commonly used to evaluate scientific manuscripts. The bibliometric method is widely used to measure scientific progress in many disciplines and becomes a common research instrument for systematic analysis of publications (Li, 2009: 39). As a research tool, Bibliometrics is selected by many researchers to read trends of research on important themes, to read large and significant impact data (Kalantari, Kamsin, Halim, Nader, Ebrahimi, and Shamshirband, 2017: 17).

The research design that fit the research problem is descriptive research design in form of content analysis. Many researchers use this design to study scientific research community trends and patterns (Piekkari, Welch, and Paavilainen, 2009: 567). The design is able to give factual explanation about research characteristic of State Islamic University Constitutional Law student theses in 5 years span, from 2013 to 2017.

The five-year period is considered sufficient for the analysis material. As recommended by Thomson Reuters(Pendlebury, 2010), a fiveyear period is sufficient to measure the impact of the study. Thus, the chosen time range in this study is relevant to the opinion that the methodological approach tends to be stable over a five year period (Hutchinson and Lovell, 2004: 383).

\section{Population and Sample}

The population of this study is the students' final assignment in Constitutional Law Study Program, State Islamic University Bandung, from 2013 to 2017, which is stored in the Central Library and Thesis 
Documentation Department of Constitutional Law. There were 115 titles found in the population. A total of 80 theses were analyzed through titles, abstracts, and content sections (Chapters I-III) to categorize the research procedures used in each thesis. The number of 80 analyzed theses is considered sufficient compared to the number of articles used by other scholars, such as Serenko and Bontis who only use 63 articles for their analysis on the same type of study (Serenko and Bontis, 2013: 138). Meanwhile, Durst and Edvardsson (2012) analyzed only 36 articles in their research on knowledge management of articles researching small and medium enterprises (Durst and Edvardsson, 2012: 880).

The examined parameters comprise of (1) constitutional law subject as research focus (2) Student's choice of research method, (3) The examined constitutional law concept, (4) research result originality. Analysis of titles, abstracts, and content sections (Chapters I-III) of the thesis is performed to determine characteristic of each thesis. The data were descriptively analyzed with quantitative approach. Researches with these characteristics and parameters fall into the knowledge management research category, which has become a recent trend among researchers.

\section{RESULTS AND DISCUSSION \\ Research Subject}

In the span of five years (2013-2017), the Constitutional Law student, are more likely to choose legislation studies as their final assignment subject. There are 53 theses that chose legislation studies, 21 chose economic development regulation subject and 3 thesis chose regulation of international relations subject. There are also found 6 theses that use irrelevant subject to the core studies of Constitutional Law.

Figure 1:

Research Subject

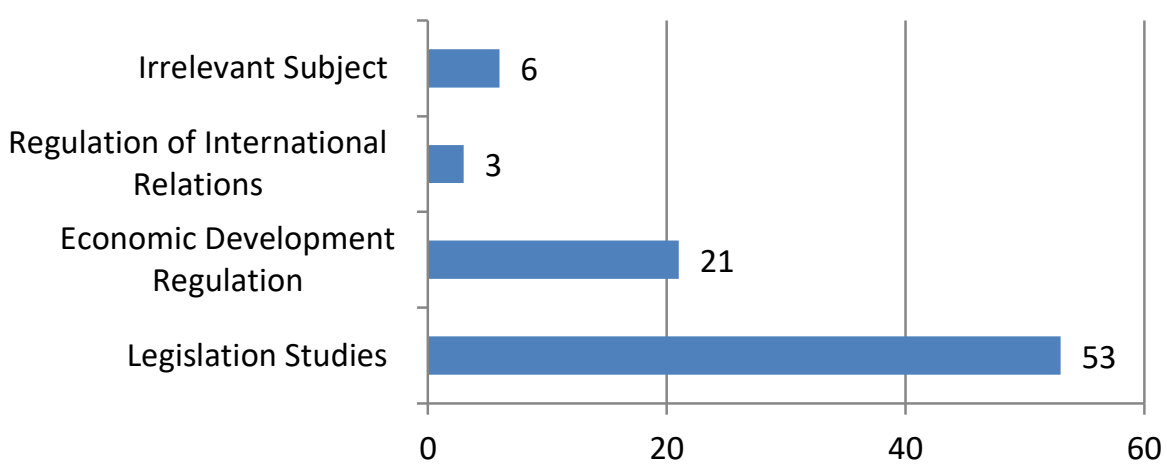

According to the figure 1 that shows research subject trend, the regulation of international relation is the lowest among other subject, while the state economic development is quite high but not as high as 
legislation studies. A total of 22 theses chose state economic development as the research subject.

The figure above also presents data about theses whose subject are irrelevant to the Constitutional Law, which is six (6) theses. The six researches theme are about economic development regulation, but they are claimed as legislation studies. The titles and their content are significantly contrast. Another study is found to be out of Constitutional Law context, its analysis variables are widen into other discipline, namely the Criminal Law. Meanwhile, one research result has two unrelated variables, because one variable went into the legislation studies while the other variable was part of the state economic development.

\section{Selected Research Methods}

Descriptive method tends to be chosen by most of Constitutional Law students in conducting research in 2013-2017 periods. Other chosen methods in a sequential trend are library studies, surveys, experiments, and comparative studies.

Figure 2: Research Method Selection

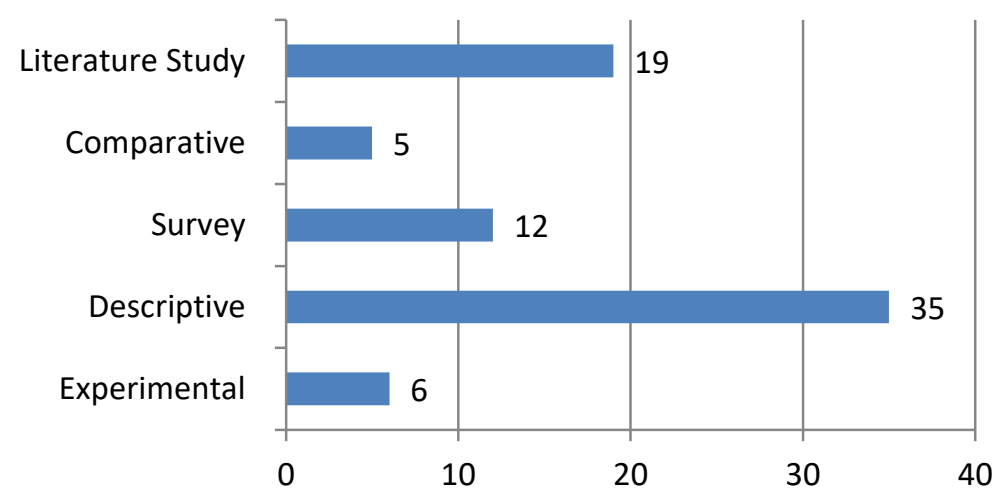

The figure 2 above shows that the trend of descriptive method selection is very high, reach $45 \%$ (35 researches). The second largest choice fell to the literature study method that reached 25\% (19 researches), followed by survey method on 16\% (12 researches) and 8\% (6 researches) chose experimental method. The least preferred method is the comparative method; only $6 \%$ or 5 studies applied it.

Of all the methods used in the researches, qualitative data analysis techniques are more dominant than quantitative. Only 2 or $3 \%$ of those theses applied quantitative techniques in their research. Meanwhile, research using qualitative techniques reached 78 thesis or $98.4 \%$. The mixture between quantitative and qualitative techniques (mixed method) was not found in the studies. 
Quantitative studies were applied by the students to test existing theories from deductive perspective. This research is lack of theory development and poorly explains the differences between variables that affect the studied phenomenon. In this case, as stated by Lukka (2010) that quantitative research has limited capacity to produce research results that present new insights.

The lack use of quantitative techniques cannot be attributed to the difficulty to obtain quantitative research theory, as some quantitative research results can be found in many journals. Perhaps, it is because students did not quite grasp the instrument and research steps of quantitative methodology. Meanwhile, the use of qualitative techniques that are dominant in Constitutional Law student research is expected to attain theory development (Ngelube, 2015: 135). The qualitative and quantitative mix techniques were not found from all of the selected theses samples. The use of mixed methods is indeed a problem in social sciences in terms of scarcity, as reported by Alise and Teddie. Both reported that they only found $5 \%$ of various social science articles using mixed methods (Alise and Teddie, 2010: 103).

\section{The Researched Constitutional Law Concept}

A concept is a formal unit of human thought, in this case the researchers. Through these formal units, the human thought is compelled to appear explicitly (Sarmah, Hazarika, and Sinha, 2015: 47). The concept of constitutional law is a formal expression of legal thinking, related to the state governance in the realm of regulation.

The exploration of all research samples found about 39 concepts of constitutional law that been studied by the students in their theses for the last five years. The top four concepts are the application of regulations, the implementing regulations, local regulations, and the application of a regulation's articles. While the less studied concepts are themes related to international relations, diplomatic, and extradition. Meanwhile, theme on policy development of state property management is quite high.

Some of the state economic development policies concepts include the management of state finances, labor protection, local revenues, and sources of state revenues. Some of these concepts served as the key of the students' research analysis. There are other concepts related to the state economic development regulation, such as reciprocity concept, right of access to public resources, and natural resources management, and others. 


\section{Figure 3: Research Concept}

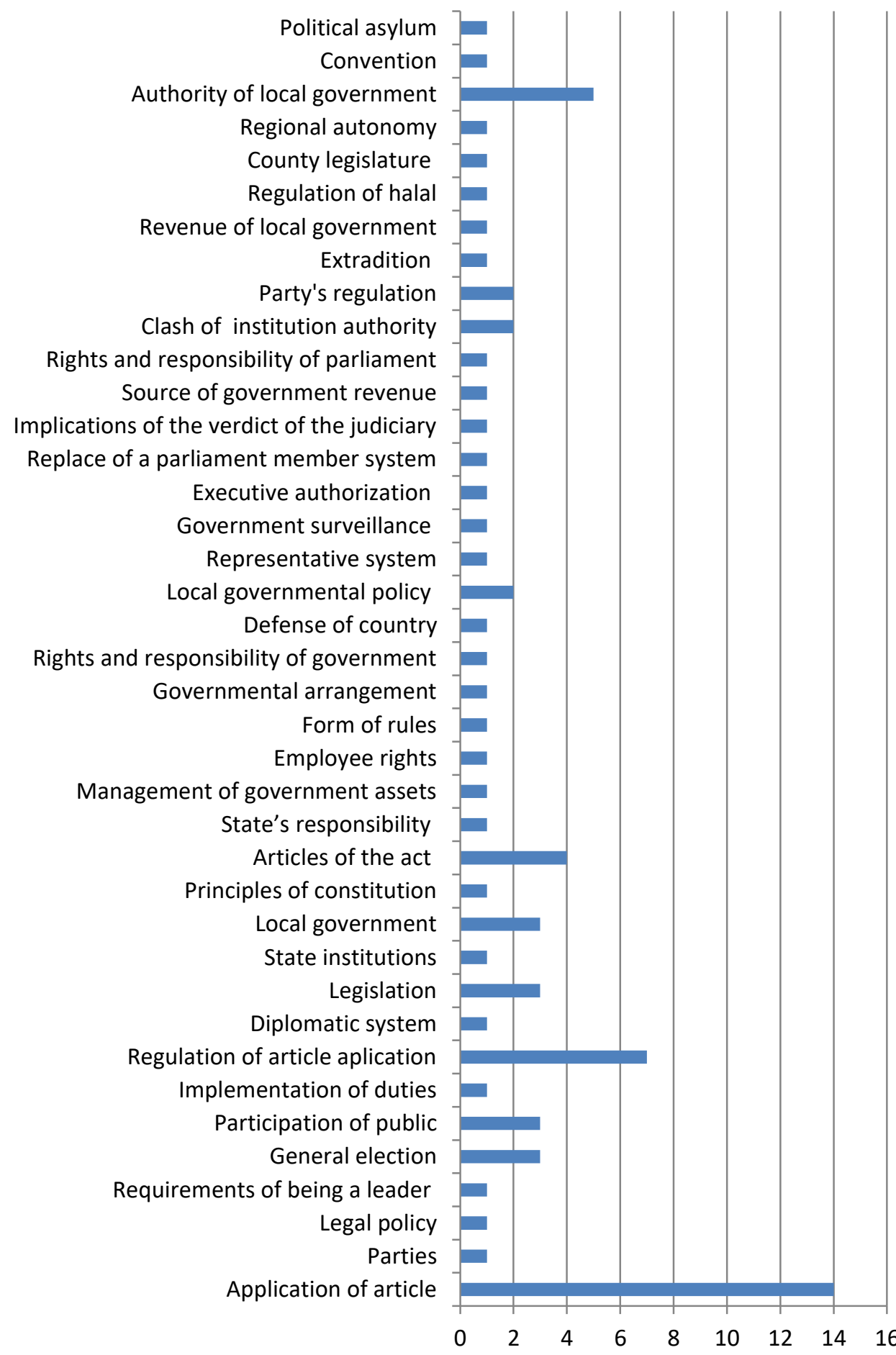

Figure 3 above displays that the most studied concept by the Constitutional Law students is the application of regulations, whether in form of act, government regulation, presidential regulations, and local regulations. The concept that is relatively large but not dominant is the 
implementing regulations of particular act, in form of government regulation, governor regulation, or mayor/regent regulation.

\section{Research Originality}

The increase of internet utilization in higher education has raised concerns over the increase of online plagiarism and cyber-cheating (Shelwyin, 2008: 465). When quoting Lambert et al.'s research results, East stated that in the United States, the number of students who admit to cheat in form of plagiarism is more than 49\%, even reaches 70\% (East, 2010: 69). While McCabe and Drinan speculate that high-grade plagiarists (students) decide to plagiarize to retain their grade (McCabe and Drinan, 1999: 46).

In some Pakistani universities, 365 alumni of undergraduate and graduate programs, both private and public universities, have low level plagiarism awareness. In addition, the universities' policy on plagiarism is very lenient and many respondents do not understand what plagiarism is. A large number of graduates admit that they deliberately plagiarized the work of others (Ramzan, Munir, Siddique, and Asif, 2012: 73). Meanwhile, at the Mozambican college, plagiarism enters a very alarming data. Based on Coughlin's research indicates that $75 \%$ of 150 theses from undergraduate and graduate programs contain significant plagiarism level (having similarities over 100 words in each thesis). Meanwhile, 39\% of the theses is worse because the similarity level is more than 500 words (Coughlin, 2015: 1-19).Saunders mapped eight plagiarism typologies: (1) self-plagiarism, (2) minor plagiarism, (3) literal plagiarism, (4) image plagiarism (5) ideas plagiarism, (6) scattergun plagiarism, (7) citation plagiarism, (8) wholesale plagiarism (Saunders, 2010: 279).

Based on the study of the entire sample (80), there are 30 theses that have similar titles to previous theses. In terms of typology, the similarities are divided into three, namely (1) similar titles, methodologies, and materials, (2) similar titles and materials but different methodologies, (3) similar titles and methodologies but different material.

Based on the three typologies of similarity above, there are 7 theses with similar title, methodology, and material. A total of 10 theses have similar title and material, but different methodology. Meanwhile, as many as 16 theses have similar title and methodology, but different material. Meanwhile, 47 theses have different titles, methodologies, and materials from previous thesis. 
Figure 4: Research Originality
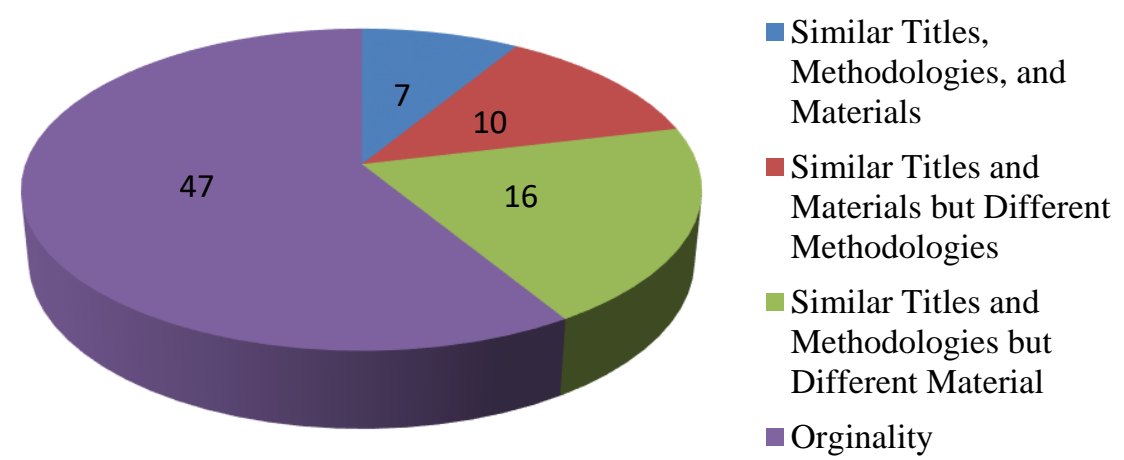

The figure 4 above depicts the percentages for samples with similarity on title, methodology, and material. There are $9 \%$ theses that have similarity on the three subjects, while samples that have similarity on title and material reaches $12 \%$; and samples that have similarity on title and methodology are $20 \%$. The rest of the samples, around $59 \%$, are being considered as original.

Related to the online plagiarism, the samples that indicate plagiarism are 28 theses, while the others 52 theses are being considered as reasonable from the research originality category. By using the plagiarism checker application from Turnitin, there are 7 theses fall into unreasonable level of similarity based on the regulation of Sunan Gunung Djati State Islamic University, which determined that the upper limit of similarity tolerance for scholarly scientific work is only $40 \%$ (Surat Keputusan Rektor UIN Sunan Gunung Djati Bandung Nomor: B240/Un.05/I.1/PP.00.9/11/2017 tentang Standar Operasional Prosedur Validasi Karya Ilmiah Mahasiswa.). Plagiarism by these seven theses can be included in the category of wholesale plagiarism, because it exceeds $40 \%$ similarity. While as many as 21 theses go under fair category according to the university regulation, because below the upper limit of similarity tolerance, so it is categorized as minor plagiarism type. 
Figure 5: Online Plagiarism

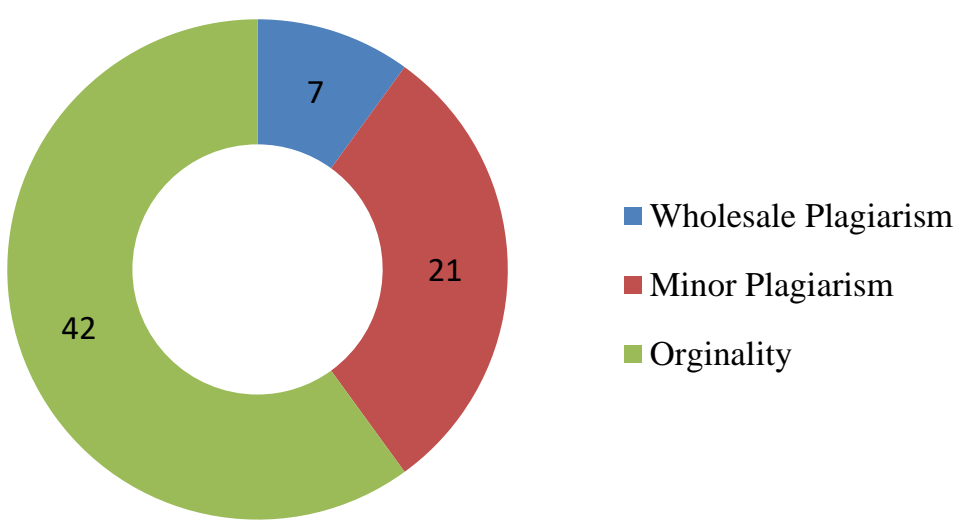

Based on Figure 5, the percentage of online plagiarism that goes into the wholesale plagiarism is $10 \%$. Meanwhile, online plagiarism that belongs to minor plagiarism typology reaches $30 \%$, as research results originality touches $60 \%$.

The originality percentage above gives a signal that the research results of Constitutional Law students are under the type of research with vulnerable integrity. The $7.10 \%$ theses that unoriginal displays dangerous zone, because it is possible that the online plagiarism number can be higher thus threatening the knowledge dignity and reduce public confidence (Krstic, 2015: 1181). This is because the online storage of scientific papers is very massive lately, so the potential of plagiarism is open widely.

\section{CONCLUSION}

This study found that research trends of UIN Sunan Gunung Djati Constitutional Law students prefer the legislation studies rather than state economic development regulations and international relation as their research subject. In terms of methods, the trend of the descriptive method is very high, reaches $45 \%$, while the lowest choice falls on the comparative method, reaches only $6 \%$. A total of 41 concepts were selected by constitutional law students for their theses research, with the most choice in four concepts, namely the application of regulations, the implementing regulations, the local regulations, and the application of an article of particular regulation. A rarely chosen concept is international relations and the management of state assets. Related to the research originality, by using Turnitin application, 28 theses indicate similarities with previous studies (with varies typology), and 52 theses are being considered as fair from the research originality category point of view 


\section{REFERENCES}

Alavi, M., \& Leidner, D. E. (2001). Review: Knowledge Management and Knowledge Management Systems: Conceptual Foundations and Research Sssues. MIS Quarterly, 25(1).

Alise, M. A. and Teddlie, C. (2010). A Continuation of the Paradigm Wars? Prevalence Rates of Methodological Approaches: Across the Social/ Behavioral Sciences. Journal of Mixed Methods Research, 4(2).

Belyaeva, E. (2012). Plagiarism as the Moral Problem of the Information Society. Socialiniu Mokslu Studijos, 4(2).

Bolivar, M. P. R., Munoz, L. A. and Hernández, A. M. L. (2012). Studying E-Government: Research Methodologies, Data Compilation Techniques and Future Outlook. Academia-Revista Latinoamericana de Administracion, 25(51).

Chancellor Decree of UIN Sunan Gunung Djati Bandung Number: B-240 / Un.05 / I.1 / PP.00.9 / 11/2017 concerning Standard Operating Procedure for Validation of Student Scientific Work.

Collier, J., \& Vallance, P. (1993). Originality: Who is to judge? The Lancet, 342(8870).

Coughlin, P. E. (2015). Plagiarism in five universities in Mozambique: Magnitude, detection techniques, and control measures. International Journal For Educational Integrity, 11(1).

Cronin, B. (2001). Acknowledgement Trends in the Research Literature of Information Science. Journal of Documentation, 57(3).

Dunford, R. (2000). Key Challenges in the Search for the Effective Management of Knowledge in Management Consulting Firms. Journal of Knowledge Management, 4(4).

Durst, S. and Edvardsson, I. R. (2012). Knowledge Management in SMEs: A Literature Review. Journal of Knowledge Management, 16 (6).

Earl, M. (2001). Knowledge Management Strategies: Toward a Taxonomy. Journal of Management Information Systems, 18(1).

East, J. (2010). Judging plagiarism: A Problem of Morality and Convention. Higher Education (00181560), 59(1).

Floress, M. T., Beschta, S. L., Meyer, K. L., \& Reinke, W. M. (2017). Praise Research Trends and Future Directions: Characteristics and Teacher Training. Behavioral Disorders, 43(1).

Guo, R., \& Sheffield, J. (2007). Paradigmatic and Methodological Examination of Knowledge Management Research: 2000-2004. Decision Support Systems, 44(3).

Göksu, I., Özcan, K. V., Çakir, R., \& Göktas, Y. (2017). Content Analysis of Research Trends in Instructional Design Models: 1999-2014. Journal Of Learning Design, 10(2). 
Hahn, J., \& Subramani, M. R. (2000). A Framework of Knowledge Management Systems: Issues and Challenges for Theory and Practice. In Ang, S., Krcmar, H., Orlikowski, J. W., Peter Weill, P., DeGross, I. J. (Eds.), Proceedings of the 21st International Conference on Information Systems, (pp. 302-312), December 10-13, 2000, Brisbane, Australia. Association for Information Systems, Atlanta, GA, USA.

Hansen, M.T., Nohria, N., \& Tierney, T. (1999). What's your Strategy for Managing Knowledge?, Harvard Business Review, 77(2).

Hutchinson, S. R. and Lovell, C. D. (2004). A Review of Methodological Characteristics of Research Published in Key Journals in Higher Education: Implications for Graduate Research Training. Research in Higher Education, 45 (4).

Horner, R. H., Carr, E. G., Halle, J., McGee, G., \& al, e. (2005). The Use of Single-Subject Research to Identify Evidence-Based Practice in Special Education. Exceptional Children, 71(2).

Jordaan, Y., Wiese, M., Amade, K. and De Clercq, E. (2013). Content Analysis of Published Articles in the South African Journal of Economic and Management Sciences. The South African Journal of Economic and Management Sciences, 16 (4).

Kalantari, A., Kamsin, A., Halim, S. K., Nader, A. E., Gani, A., Ebrahimi, A., \& Shamshirband, S. (2017). A Bibliometric Approach to Tracking Big Data Research Trends. Journal of Big Data, 4(1).

Kautz, K. (2002). Using IT to Support Knowledge Management-A Surveybased Study of a Large Global Consulting Company. Informing Science, June.

Krstić, S. (2015). Research Integrity Practices from the Perspective of EarlyCareer Researchers. Science \& Engineering Ethics, 21(5).

Li LL, et al. (2009). Global Stem Cell Research Trend: Bibliometric Analysis as a Tool for Mapping of Trends from 1991 to 2006. Scientometrics, 80(1).

Lukka, K. (2010). The Roles and Effects of Paradigms in Accounting Research. Management Accounting Research, 21: 110115.

McCabe, D., \& Drinan, P. (1999). Toward a culture of academic integrity. Chronicle of Higher Education, Oct 15, 46, 8. Retrieved May 14, 2018 from http:/ / ieeexplore.ieee.org/iel5/7628/20808/00963948.pdf.

Ngulube, P. (2015). Trends in Research Methodological Procedures Used in Knowledge Management Studies. African Journal of Library, Archives \& Information Science, 25(2).

Ngulube, P. (2015). Qualitative Data Analysis and Interpretation: Systematic Search for Meaning. In Mathipa, E. R. and Gumbo, M. T, (eds.), Addressing Research Challenges: Making Headway for 
Developing Researchers. Noordwyk: Mosala-MASEDI Publishers and Booksellers cc., pp. 134-153.

Nonaka, I., \& Peltokorpi, V. (2006). Objectivity and Subjectivity in Knowledge Management: A Review of 20 Top Articles. Knowledge and Process Management, 13(2).

Piekkari, R., Welch, C. and Paavilainen, E. (2009). The Case Study as Disciplinary Convention: Evidence from International Business Journals. Organizational Research Methods, 12 (3).

Pendlebury, D. A. (2010). White Paper: Using Bibliometrics in Evaluating Research. Philadelphia, PA: Thomson Reuters.

Ramzan, M., Munir, M., Siddique, N., \& Asif, M. (2012). Awareness about Plagiarism Amongst University Students in Pakistan. Higher Education (00181560), 64(1).

Roztocki, N., \& Weistroffer, H. R. (2015). Information and Communication Technology in Transition Economies: An Assessment of Research Trends. Information Technology For Development, 21(3).

Sarmah, A. K., Hazarika, S. M., \& Sinha, S. K. (2015). Formal Concept Analysis: Current Trends and Directions. The Artificial Intelligence Review, 44(1).

Saunders, J. (2010). Plagiarism and the Law. Learned Publishing, 23(4).

Schulz, M., \& Jobe, L.A. (1998). Codification and Tacitness as Knowledge Management Strategies: An Empirical Exploration. Carnegie Bosch Foundation, Pittsburgh, PA, USA, 1998.

Scheepers, R., Venkitachalam, K., \& Gibbs, M. R. (2004). Knowledge Strategy in Organizations: Refining the Model of Hanser, Nohria, and Tierney. Journal of Strategic Information Systems, 13(3).

Serenko, A. and Bontis, N. (2009). Global Rankings of Knowledge Management and Intellectual Capital Academic Journals. Journal of Knowledge Management, 13 (1).

Serenko, A. and Bontis, N. (2013). The Intellectual Core and Impact of the Knowledge Management Academic Discipline. Journal of Knowledge Management, 17 (1).

Selwyn, N. (2008). 'Not Necessarily A Bad Thing: A Study of Online Plagiarism Amongst Undergraduate Students. Assessment \& Evaluation In Higher Education, 33(5).

Shenton, A. K. (2010). This Problem of Plagiarism... Just what Can We Do About It? The School Librarian, 58(2).

Shin, I. (2017). Recent Research Trends in Meta-analysis. Asian Nursing Research, 11(2).

Stallings, R. A. and Ferris, J. A. (1988). Public Administration Research: Work in PAR, 19401984. Public Administration Review, 48 (1). 
Surat Keputusan Rektor UIN Sunan Gunung Djati Bandung Nomor: B240/Un.05/I.1/PP.00.9/11/2017 tentang Standar Operasional Prosedur Validasi Karya Ilmiah Mahasiswa.

Xie, S., J. Zhan \& Y. Ho. 2008. Assessment of World Aerosol Research Trends by Bibliometric Analysis. Scientometrics. 77. 


\section{Halaman ini sengaja di kosongkan}

